\title{
PUS CELL AND BACTERIAL COUNTS IN THE DIAGNOSIS OF URINARY TRACT INFECTIONS IN CHILDHOOD
}

\author{
BY \\ I. B. HOUSTON \\ From the Department of Child Health, the University of Manchester
}

(RECEIVED FOR PUBLICATION MARCH 18, 1963)

The techniques used to examine urine with a view to determining whether or not it is infected vary widely. Although the results produced at any one hospital are usually reproducible and, with experience, interpretable, it is often difficult or impossible to compare accurately these findings with those of any other hospital. This state of affairs is sufficiently disturbing, but there also exists doubt as to whether assessment of pyuria (Stansfeld and Webb, 1953; Stansfeld, 1962) or bacteriuria (Kass, 1956, 1957; Sanford, Favour, Mao and Harrison, 1956; Pryles, 1960) is better as an indication of infection of urine.

These considerations have prompted an investigation into the techniques used to distinguish the presence of a urinary infection and in particular to compare the value of pus cell and bacterial counts and the influence the technique of collection exerts upon them.

\section{Selection of Patients}

Urine specimens were collected, using several different techniques from two groups of patients.

Group I: Infants and children admitted to hospital with conditions other than urinary infection, renal disease or conditions known to affect the cellular or bacterial content of the urine and who were not receiving antibiotic therapy.

Group II: Patients whose clinical condition was compatible with a diagnosis of acute urinary infection and from whom the specimen was collected before therapy was undertaken.

It is realized that children in Group I were not necessarily 'normal' with respect to their urinary findings, in that they were sick, but it was to distinguish just such children from those who were sick because of a urinary infection that this investigation was primarily undertaken. It is therefore felt that Group I represents a fair control group for comparison with patients suffering from urinary infections.

All these specimens were then examined and pus cell and bacterial counts performed on each one.
Techniques

In children of both sexes, who were sufficiently old to be co-operative (usually more than 3 years old) clean specimens of urine were obtained by first thoroughly swabbing the genital skin with an antiseptic solution (aqueous $0.1 \%$ chlorhexidine or $1 \%$ cetrimide); the child was asked to void urine into a sterile container, and the specimen was immediately refrigerated. At a later stage of the investigation a special sterilized glass tube (Fig. 1) was used to collect clean specimens from girls, the expanded end of the tube being held over the urethral orifice during micturition; the technique was otherwise as above.

In infants and toddlers, those unable or unwilling to co-operate, other techniques were tried. In male infants, after the usual thorough sterilization of the genital skin and glans penis, either a piece of sterilized (autoclaved) Paul's tubing ( in the distal end or a clean (not necessarily sterile) disposable plastic urine collection bag (Downs) was fixed in position by adhesive plaster. In female infants either a similar plastic bag or another special sterilized glass collector (Fig. 2) was applied after preliminary cleansing of the skin. When the collector was used, knotted, sterilized Paul's tubing was attached to the distal end of the glass tube and the proximal end (covered in adhesive plaster to prevent accidental damage from the glass) was applied over the urethral orifice and held in position with adhesive strapping.

The Group I collections were made in two wards with the minimum disruption of ward routine by a number of nurses and sisters of varying experience at varying times of the day. The necessity of thorough disinfection of the skin, careful aseptic technique during application, frequent inspection of the infants until they micturated and prompt refrigeration of the specimen was emphasized. Specimens of urine were refrigerated (at 4-6 ${ }^{\circ} \mathrm{C}$.) immediately after collection (unless they were to be examined within an hour) and always examined within 24 hours, the great majority within six hours. It has been demonstrated several times that the bacterial count of urine refrigerated at $4-6^{\circ} \mathrm{C}$. does not alter for several days (Pryles, 1960; Kass, 1956). On the other hand Meynell (1958) and Gorrill and McNeil (1960) have shown that 


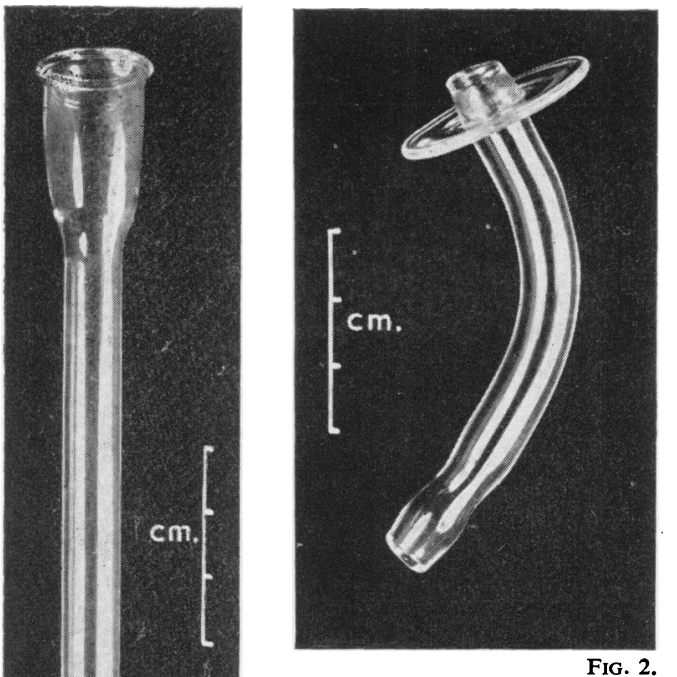

FIG. 1.-Glass collector for older female children.

FIG. 2.-Glass collector for female infants. Adhesive strapping is applied over the glass flange to keep the collector in place; the shorter end is placed over the urethral orifice and sterilized Paul's tubing is attached to the longer end.

FIG. 1.

sudden chilling of cultures of rapidly multiplying Esch. coli or Pseudomonas pyocyanea, produced by mixing the culture with various diluents at $4^{\circ} \mathrm{C}$., causes the death of many bacterial cells. This effect depends on several variables: the nature both of the original culture medium and of the diluent solution, the phase of growth of the culture, and particularly the rate of cooling. Only sudden chilling is lethal-more gradual cooling (over 30 min.) is innocuous (Sherman and Cameron, 1934; Hegarty and Weeks, 1940; Meynell, 1958; Gorrill and McNeil, 1960). In the present study it took approximately two hours for the urine specimens to cool from $37^{\circ} \mathrm{C}$. to $4^{\circ} \mathrm{C}$. and this may partially explain why this lethal effect has not been noticed in the present series nor in others using refrigerated specimens.

Pus cell counts were done on fresh, uncentrifuged, well-mixed urine in a Fuchs-Rosenthal counting chamber -a complete c.mm. of the urine being counted unless the count was so high as to make this impracticable, in this case the urine was suitably diluted in $0.9 \%$ saline and recounted. It was found that allowing a drop of $0.1 \%$ Nile blue stain to dry on the slide before adding the urine helped to identify the pus cells more easily and facilitated their counting.

Bacterial counts were done by the method described by Kass (1956); $1 \mathrm{ml}$. of each suitable dilution of the urine was mixed with molten nutrient agar and poured into a sterile empty Petri-dish to set, the number of colonies being counted after 48 hours incubation at $37^{\circ} \mathrm{C}$. Specimens of Group I were routinely diluted 100 times and $1 \mathrm{ml}$. of this dilution used to mix with the agar; specimens of Group II had at least two dilutions of $1 / 100$ and $1 / 10,000$ made and treated in the same way.

In addition to these tests each specimen from Group II was examined and cultured by the usual laboratory procedures, the organism being identified and its sensitivity to antibacterial agents determined.

\section{Results}

Group I consisted of 213 specimens from 187 individuals and Group II of 68 specimens from 49 individuals.

Tables 1-4 show the results obtained on examination of both groups of specimens. By an examination of these results it will be seen that where the pus cell count is less than $10 / \mathrm{c} . \mathrm{mm}$. the specimen can be regarded as uninfected with almost complete certainty, where the pus cell count is greater than $100 /$ c.mm. the urine is equally likely to be infected. Pus cell counts of $10-100 /$ c.mm. must be regarded as dubious and should be repeated but generally pus cell counts of less than $50 / \mathrm{c} . \mathrm{mm}$. are due to contamination in collection and those greater than $50 / \mathrm{c} . \mathrm{mm}$. are probably infected. With regard to bacterial counts, less than $10^{4}$ bacteria $/ \mathrm{ml}$. implies an uninfected urine, more than $10^{6} / \mathrm{ml}$. implies a urinary infection; values between these two must be regarded as dubious but between $10^{4}$ and $10^{5}$ bacteria $/ \mathrm{ml}$. are likely to prove to be due to contamination and greater than $10^{5} / \mathrm{ml}$. likely to be due to infection.

A further study of these results will show, as is to be expected, a moderate scatter of results as regards both parameters measured, but it is of interest that only a very small number of specimens in either Group I or II failed to be either frankly normal or frankly abnormal on at least one count. This is demonstrated in Table 5 where only $12 / 213$ in Group I and 2/68 in Group II remained 'dubious' when both bacterial and pus cell counts were considered together.

\section{Discussion}

Collection Techniques. It has been stated (Pryles, 1960) that 'if a proper specimen (of urine) is to be obtained it must be collected by the physician in charge or under his direct supervision; the collection cannot be entrusted to a clinical clerk or student nurse'. Yet more recently, Turner (1961) felt that special preparation was unnecessary in collecting the urine specimen for bacterial count; this view was challenged by Kass (1962). 
TABLE 1: GROUP I, NON-INFECTED URINES

\begin{tabular}{|c|c|c|c|c|c|c|c|c|}
\hline \multirow{2}{*}{$\begin{array}{l}\text { Pus Cell } \\
\text { Count / } \\
\text { c.mm. }\end{array}$} & \multicolumn{7}{|c|}{ Technique of Collection } & \multirow[b]{2}{*}{ Total } \\
\hline & $\begin{array}{l}\text { Clean } \\
\text { Specimen } \\
\text { (male) }\end{array}$ & $\begin{array}{c}\text { Clean } \\
\text { Specimen } \\
\text { (female) }\end{array}$ & $\begin{array}{l}\text { Clean Specimen } \\
\text { With Collector } \\
\text { (female) }\end{array}$ & $\begin{array}{l}\text { Catheter } \\
\text { Specimen } \\
\text { (female) }\end{array}$ & $\begin{array}{l}\text { Infant } \\
\text { Collector } \\
\text { (female) }\end{array}$ & $\begin{array}{l}\text { Paul's } \\
\text { Tubing } \\
\text { (male) }\end{array}$ & $\begin{array}{c}\text { Plastic Bag } \\
\text { (male and } \\
\text { female) }\end{array}$ & \\
\hline $0-10$ & 35 & 30 & 18 & 12 & 8 & 32 & 27 & $\begin{array}{c}162 \\
(76 \%)\end{array}$ \\
\hline $11-50$ & 5 & 13 & 5 & 4 & 5 & 4 & 7 & $\begin{array}{c}43 \\
(20 \%)\end{array}$ \\
\hline $51-100$ & 0 & 2 & 2 & 0 & 0 & 0 & 0 & $(2 \%)$ \\
\hline$>100$ & 0 & 2 & 0 & 0 & 1 & 1 & 0 & $(2 \%)$ \\
\hline
\end{tabular}

TABLE 2: GROUP II, INFECTED URINES

\begin{tabular}{|c|c|c|c|c|c|c|c|c|}
\hline \multirow{2}{*}{$\begin{array}{l}\text { Pus Cell } \\
\text { Count/ } \\
\text { c.mm. }\end{array}$} & \multicolumn{7}{|c|}{ Technique of Collection } & \multirow[b]{2}{*}{ Total } \\
\hline & $\begin{array}{c}\text { Clean } \\
\text { Specimen } \\
\text { (male) }\end{array}$ & $\begin{array}{c}\text { Clean } \\
\text { Specimen } \\
(\text { female })\end{array}$ & $\begin{array}{l}\text { Clean Specimen } \\
\text { With Collector } \\
\text { (female) }\end{array}$ & $\begin{array}{l}\text { Catheter } \\
\text { Speciman } \\
\text { (female) }\end{array}$ & $\begin{array}{l}\text { Infant } \\
\text { Collector } \\
\text { (female) }\end{array}$ & $\begin{array}{l}\text { Paul's } \\
\text { Tubing } \\
\text { (male) }\end{array}$ & $\begin{array}{c}\text { Plastic Bag } \\
\text { (male and } \\
\text { female) }\end{array}$ & \\
\hline $0-10$ & 0 & 0 & 0 & 0 & 0 & 1 & 0 & $(1.5 \%)$ \\
\hline $11-50$ & 0 & 3 & 0 & 0 & 0 & 0 & 1 & $(6 \%)$ \\
\hline $51-100$ & 2 & 0 & 1 & 0 & 0 & 0 & 1 & $(6 \%)$ \\
\hline$>100$ & 10 & 15 & 8 & 7 & 0 & 2 & 17 & $\begin{array}{c}59 \\
(86 \cdot 5 \%)\end{array}$ \\
\hline
\end{tabular}

TABLE 3: GROUP I, NON-INFECTED URINES

\begin{tabular}{|c|c|c|c|c|c|c|c|c|c|}
\hline \multirow[b]{2}{*}{$\begin{array}{c}\text { Bacterial } \\
\text { Count } / \mathrm{ml} \text {. }\end{array}$} & \multicolumn{7}{|c|}{ Technique of Collection } & & \multirow[b]{2}{*}{ Total } \\
\hline & $\begin{array}{c}\text { Clean } \\
\text { Specimen } \\
\text { (male) }\end{array}$ & $\begin{array}{c}\text { Clean } \\
\text { Specimen } \\
\text { (female) }\end{array}$ & $\begin{array}{l}\text { Clean Specimen } \\
\text { With Collector } \\
\text { (female) }\end{array}$ & $\begin{array}{c}\text { Catheter } \\
\text { Specimen } \\
\text { (female) }\end{array}$ & $\begin{array}{l}\text { Infant } \\
\text { Collector } \\
\text { (female) }\end{array}$ & $\begin{array}{l}\text { Paul's } \\
\text { Tubing } \\
\text { (male) }\end{array}$ & $\begin{array}{c}\text { Plastic Bag } \\
\text { (male and } \\
\text { female) }\end{array}$ & & \\
\hline $0-10^{4}$ & 36 & 39 & 22 & 15 & 14 & 16 & 18 & & $\begin{array}{l}160 \\
(75 \%)\end{array}$ \\
\hline $10^{4}-10^{5}$ & 4 & 8 & 3 & 1 & 0 & 16 & 12 & 1 & $\begin{array}{c}44 \\
(21 \%)\end{array}$ \\
\hline $10^{5}-10^{6}$ & 0 & 0 & 0 & 0 & 0 & 5 & 4 & & $\left(\begin{array}{c}9 \\
(4)\end{array}\right.$ \\
\hline$>10^{6}$ & 0 & 0 & 0 & 0 & 0 & 0 & 0 & & 0 \\
\hline
\end{tabular}

TABLE 4: GROUP II, INFECTED URINES

\begin{tabular}{|c|c|c|c|c|c|c|c|c|}
\hline \multirow[b]{2}{*}{$\begin{array}{c}\text { Bacterial } \\
\text { Count } / \mathrm{ml} \text {. }\end{array}$} & \multicolumn{7}{|c|}{ Technique of Collection } & \multirow[b]{2}{*}{ Total } \\
\hline & $\begin{array}{c}\text { Clean } \\
\text { Specimen } \\
\text { (male) }\end{array}$ & $\begin{array}{c}\text { Clean } \\
\text { Specimen } \\
\text { (female) }\end{array}$ & $\begin{array}{c}\text { Clean Specimen } \\
\text { With Collector } \\
\text { (female) }\end{array}$ & $\begin{array}{c}\text { Catheter } \\
\text { Specimen } \\
\text { (female) }\end{array}$ & $\begin{array}{l}\text { Infant } \\
\text { Collector } \\
\text { (female) }\end{array}$ & $\begin{array}{l}\text { Paul's } \\
\text { Tubing } \\
\text { (male) }\end{array}$ & $\begin{array}{l}\text { Plastic Bag } \\
\text { (male and } \\
\text { female) }\end{array}$ & \\
\hline $0-10^{4}$ & 0 & 0 & 0 & 0 & 0 & 0 & 0 & 0 \\
\hline $10^{4}-10^{5}$ & 3 & 0 & 0 & 1 & 0 & 0 & 0 & $\left(\begin{array}{c}4 \\
(6 \%)\end{array}\right.$ \\
\hline $10^{5}-10^{6}$ & 1 & 1 & 0 & 1 & 0 & 0 & 4 & $\begin{array}{c}7 \\
(10 \%)\end{array}$ \\
\hline$>10^{6}$ & 8 & 17 & 9 & 5 & 0 & 3 & 15 & $\begin{array}{c}57 \\
(84 \%)\end{array}$ \\
\hline
\end{tabular}


TABLE 5

COMPARISON OF PUS CELL AND BACTERIAL COUNTS FOUND IN INDIVIDUAL URINE SPECIMENS

\begin{tabular}{|c|c|c|c|c|c|c|c|c|}
\hline \multirow{3}{*}{$\begin{array}{l}\text { Pus } \\
\text { Cells/ } \\
\text { c.mm. }\end{array}$} & \multicolumn{8}{|c|}{ Bacteria/ml. } \\
\hline & \multicolumn{2}{|c|}{$0-10^{4}$} & \multicolumn{2}{|c|}{$10^{4}-10^{5}$} & \multicolumn{2}{|c|}{$10^{5}-10^{6}$} & \multicolumn{2}{|c|}{$>10^{6}$} \\
\hline & Normal & Infected & Normal & Infected & Normal & Infected & Normal & Infected \\
\hline $0-10$ & 121 & 0 & 33 & 0 & 8 & 0 & 0 & 1 \\
\hline $11-50$ & 33 & 0 & 9 & 0 & 1 & 1 & 0 & 3 \\
\hline $51-100$ & 2 & 0 & 2 & 0 & 0 & 1 & 0 & 3 \\
\hline$>100$ & 4 & 0 & 0 & 4 & 0 & 5 & 0 & 50 \\
\hline
\end{tabular}

Note the small number of specimens that remain 'dubious' on both counts if these are considered together, i.e. the bold figures.

The italic figures in the corners represent specimens that could be falsely interpreted if only one parameter were used for assessment.

The present investigation was undertaken on lines intermediate to these opposing views, for while accepting as an ideal Pryles' statement it was felt that this was hardly a practical proposition for routine practice. Accordingly, the collection of urine specimens, while as meticulous as reasonably possible, was done by the usual staff on the ward with the minimum disruption of ward routine.

It will be seen from the results that clean specimens collected from the continent co-operative male and female patients of the older age-group (mainly more than 3 years old) were most satisfactory, so were those collected with the special glass collector from female infants. However, specimens collected in plastic bags or with sterilized Paul's tubing were much more liable to bacterial contamination and misinterpretation. This finding must always be borne in mind in considering the bacteriology of urine specimens obtained in this way.

That the difference in bacterial counts in the urine of infants is attributable to contamination has been shown by Pryles, Lüders and Alkan (1961) who compared paired 'clean' and catheter specimens of urine from normal and infected infants. It is interesting that the urinary bacterial counts from infants reported in the present paper fall between those quoted by Pryles et al. (1961) for urines collected by clean voiding (using a more meticulous technique than used here) and those collected at random; this presumably reflects a degree of care in collection also intermediate between the two extremes.

The position as regards pus cell counts was more satisfactory with all techniques of collection and, as would be expected, it was among the older females that such cellular contamination was found most often. This latter seemed to be diminished by using a glass tube as previously described though the numbers are too small to be significant.

Figures for catheter specimens of urine are included in Group I and as already demonstrated by Pryles and Steg (1959) give results very similar to those obtained with simple clean urine specimens from older children. Marple (1941) reported that $6 \%$ (4 of 69) of women with previously uninfected urine developed a frank infection following a single catheterization of the bladder. Kass $(1956,1957)$ reported a $2-4 \%$ incidence of 'true bacteriuria' (i.e. greater than $10^{5}$ organisms $/ \mathrm{ml}$. urine) after a single catheterization, but how many of these had other evidence of infection is not stated. In the same paper an indwelling catheter (for 96 hours) was associated with $98 \%$ incidence of 'true bacteriuria'. Brumfitt, Davies and Rosser (1961) found a $9 \cdot 1 \%$ incidence of urinary infection in obstetric patients following catheterization of the bladder as compared with $4.7 \%$ in a control group of similar patients who were not catheterized. On the other hand Pryles, Atkin, Morse and Welch (1959) point out that in the course of a comparative study of urine obtained by suprapubic aspiration and catheterization of the bladder, organisms were introduced, inadvertently, into the bladder in 17 of 42 children, but none of the children developed urinary infections on follow-up of four to six months' duration. None of the patients in the present series is known to have developed infections following bladder catheterization.

A consideration of these findings seems to imply that catheterization of the bladder can and should be avoided in most circumstances but that if repeated specimens obtained by 'clean voiding' remain dubious then catheterization remains a very useful technique.

Pyuria. With regard to pus cell counts, the present work agrees closely with that of Stansfeld and Webb (1953) and confirms that pus cell counts of uncentrifuged urine are a valid and reproducible way of assessing pyuria. More recently Houghton 
and Pears (1957), Hutt, Chalmers, MacDonald and De Wardener (1961) and Little (1962) have established normal values for pus cell excretion per hour -an estimate that allows for the variation in the concentration of the urine and is therefore more accurate than a result expressed per c.mm. They are generally agreed that very few normal adults excrete more than 200,000 white cells per hour and the majority a good deal less. There are, however, no comparable figures for infants and children, largely because of the added difficulty of collecting accurately timed specimens, without catheterization, from this age-group.

Stansfeld (1962) and Little (1962) have both found assessment of pyuria in terms of the number of pus cells per high power field unreliable and the widespread use of this technique probably accounts, in part, for the uncertainties expressed about the value of pyuria in the diagnosis of urinary infections (Pryles, 1960).

Bacteriuria. The results obtained in Group I for bacterial counts of the urine compare well with those of Kass (1956) and Pryles and Steg (1959) though the scatter of results is wider for the reasons already mentioned when discussing the collection techniques. These authors have suggested a level of greater than $10^{5}$ bacteria $/ \mathrm{ml}$. of urine as indicative of urinary infection. The present results support this suggestion except that a bacterial count of between $10^{5}$ and $10^{6}$ bacteria $/ \mathrm{ml}$. in a specimen from an infant requires confirmation by repetition before it is accepted as evidence of infection.

Comparative Value of Pyuria and Bacteriuria. Each of these techniques produces a number of dubious or false results; in the present series, within Group I, 51/213 (23\%), if pus cells are considered, and $53 / 213(25 \%)$, if bacterial counts are used as the criterion; within Group II the figures are 9/68 $(13 \%)$ and $11 / 68(16 \%)$, respectively. If both sets of results are considered together for each specimen then only $12 / 213(6 \%)$ in Group I and 2/68 (3\%) in Group II are dubious on both counts; all the other specimens fall firmly within the 'normal' or 'abnormal' groups on one basis or the other-strong evidence for their interpretation as infected or not.

Stansfeld (1962) and McGeachie and Kennedy (1963) have compared pus cell and bacterial counts in the same urine specimens and both reports show a broad correlation between these two measurements. However, in neither report is a clinical correlation of the results attempted and they therefore differ from the present series in which the distinction between specimens of Group I and Group II is primarily a clinical one. Osborn and
Smith (1963) have compared urinary pus cell counts, pus cell excretion rates and bacterial counts with one another. They found that all 19 urine specimens with bacterial counts of more than $10^{5}$ bacteria $/ \mathrm{ml}$. had pus cell excretion rates of more than 200,000 pus cells/hour, but only nine of the 19 had more than 50 pus cells/c.mm. This is not, however, representative of the actual association of abnormal pus cell and bacterial counts, for the specimens were specially selected because of the relative preponderance of bacteria over pus cells found in the preliminary laboratory tests; again no information is given about the nature of the illnesses from which these patients suffered. A consideration of the above reports and the results reported herein suggests that accurate measurement of pyuria is no less precise a way of defining the presence of a urinary infection than the measurement of bacteriuria. However, in doubtful cases the diagnosis is greatly aided by measurements of both values, and in a small minority of patients a urinary infection may be present without significant pyuria.

It should be remembered that the patients in Group II had some form of illness, though often vague and non-specific. It has been shown that in some situations asymptomatic bacteriuria may be significant, for instance in pregnancy (Turner, 1961; Kass, 1957) and the present investigation casts no light on the interpretation in paediatric practice, of such bacteriuria without either pyuria or clinical evidence of infection.

\section{Summary}

The range of values of pus cell and bacterial counts of two contrasting groups of patients, one with no evidence of renal disease or urinary infection and one with acute symptomatic urinary infections, is compared.

The techniques used to collect the urine have been assessed and the difficulty of obtaining satisfactory 'clean' specimens from infants is stressed.

It is suggested that in the diagnosis of urinary tract infections pus cell and bacterial counts of the urine are complementary to one another and that both tests done together produce more reliable results than either alone.

I should like to thank the physicians and surgeons of the Royal Manchester Children's Hospital for permission to study patients in their care and especially Professor W. F. Gaisford and Dr. G. M. Komrower for their encouragement and advice. I am also deeply indebted to the nursing staff for their assistance, to Dr. H. B. Marsden for permitting me to use the facilities of the hospital laboratories and to Mr. A. Bailey of the Department of Medical Illustration for help with the Tables and figures. 
REFERENCES

Brumfitt, W., Davies, B. I. and Rosser, E. Ap I. (1961). Urethral catheter as a cause of urinary-tract infection in pregnancy and puerperium. Lancet, $2,1059$.

Gorrill, R. H. and McNeil, E. M. (1960). The effect of cold diluent on the viable count of Pseudomonas pyocyanea. J. gen. Microbiol., 22, 437

Hegarty, C. P. and Weeks, O. B. (1940). Sensitivity of Escherischia coli to cold-shock during the logarithmic growth phase. J. Bact., $39,475$.

Houghton, B. J. and Pears, M. A. (1957). Cell excretion in normal urine. Brit. med. J., 1, 622.

Hut t, M. S. R. Chalmers, J. A., MacDonald, J. S. and De Wardener, H. E. (1961). Pyelonephritis; Observations on the relation H. E. (1961). Pyelonephritis; Observations on the

Kass, E. H. (1956). Asymptomatic infections of the urinary tract. Trans. Ass. Amer. Phycns, 69, 56.

- (1957). Bacteriuria and the diagnosis of infections of the urinary tract. Arch. intern. Med., 100, 709.

(1962). Bacilluria in pregnancy. Lancet, 1, 46

Little, P. J. (1962). Urinary white-cell excretion. ibid., 1, 1149.

McGeachie, J. and Kennedy, A. C. (1963). Simplified quantitative methods for bacteriuria and pyuria. J. clin. Path., 16, 32.

Marple, C. D. (1941). The frequency and character of urinary tract infections in an unselected group of women. Ann. intern. Med., 14, 2220.
Meynell, G. G. (1958). The effect of sudden chilling on Escherichia coli. J. gen. Microbiol., 19, 380.

Osborn, R. A. and Smith, A. J. (1963). A comparison of quantitative methods in the investigation of urinary infections. J.clin. Path.,

16, 46. Vryles, C. (1960). The diagnosis of urinary tract infection. Pediatrics, 26, 441 .

_, Atkin, M. D., Morse, T. S. and Welch, K. J. (1959). Comparative bacteriologic study of urine obtained from children by percutaneous suprapubic aspiration of the bladder and by catheter. ibid., 24, 983.

- Lüders, D. and Alkan, M. K. (1961). A comparative study of bacterial cultures and colony counts in paired specimens of urine obtained by catheter versus voiding from normal infants and infants with urinary tract infection. ibid., 27, 17.

_ and Steg, N. L. (1959). Specimens of urine obtained from young girls by catheter versus voiding. ibid., 23, 441 .

Sanford, J. P., Favour, C. B., Mao, F. H. and Harrison, J. H. (1956). Evaluation of the 'positive' urine culture. Amer. J. Med., 20, 88.

Sherman, J. M. and Cameron, G. M. (1934). Lethal environmental factors within the natural range of growth $J$. Bact, 27, 341 .

Stansfeld, J. M. (1962). The measurement and meaning of pyuria. Arch. Dis. Childh., 37, 257.

- and Webb, J. K. G. (1953). Observations on pyuria in children. ibid., 28, 386

Turner, G. C. (1961). Bacilluria in pregnancy. Lancet, 2, 1062. 